\title{
THE PROTHROMBIN CONVERSION ACCELERATOR OF SERUM (SPCA) : ITS PARTIAL PURIFICATION AND ITS PROPERTIES COMPARED WITH SERUM AC-GLOBULIN ${ }^{1}$
}

\author{
By BENJAMIN ALEXANDER, ROBERT GOLDSTEIN, AND GRETA LANDWEHR \\ WITH THE TECHNICAL ASSISTANCE OF EUNICE ADDELSON
}

\author{
(From the Yamins Research Laboratory, Beth Israel Hospital, and the Department of Medicine, \\ Harvard Medical School, Boston)
}

(Submitted for publication January 6, 1950; accepted, March 20, 1950)

\section{INTRODUCTION}

The conversion of prothrombin to thrombin during normal coagulation proceeds with ever increasing velocity until at the moment of clotting, or shortly thereafter, thrombin evolution is explosive. This phenomenon, referred to as the "autocatalytic" nature of thrombin formation, remains unexplained. It is evident that abnormalities in this reaction may underlie the pathogenesis of certain hemorrhagic disorders on the one hand, or of excessive intravascular coagulation, on the other.

Considerable progress has recently been made toward elucidating the mechanism of the autocatalytic process by the discovery of substances which, arising during coagulation, accelerate, activate or otherwise act as ancillary agents in the conversion of prothrombin by thromboplastin plus calcium. Ware and his colleagues (1-4) have separated a protein fraction from bovine serum, serum Ac-globulin, which is said to arise from the interaction of thrombin with a relatively inert precursor, plasma Ac-globulin. This moiety increases the velocity of thrombin formation as well as the amount of thrombin formed, in an isolated system containing prothrombin, thromboplastin and calcium. Owren (5) described the evolution during clotting of a substance with similar properties, Factor VI, and Alexander and his associates reported on a prothrombin conversion accelerator in serum, spca (6-9). Milstone (10), too, observed the transformation in the first phase of clotting of a plasma globulin, prothrombokinase, into an active enzyme, thrombokinase, which accelerates not only prothrombin conversion but also its own elaboration. A "prothrombin-converting factor" in serum has also been described by Jacox (11).

\footnotetext{
1 Supported by a grant from the Commonwealth Fund.
}

That these entities are entirely different is highly unlikely. It would be more reasonable to assume that they are identical, and that their apparent dissimilarities reflect differences in technique, in purity and source of material, and in interpretations. Definite conclusions, however, regarding the relationship of the various factors must await simultaneous comparative studies of the substances in purified form.

The purpose of this paper is to report such a study, on two of these factors, made possible by the successful separation and partial purification of spca and by the generosity of Dr. Walter $\mathrm{H}$. Seegers in furnishing us with a preparation of serum Ac-globulin. Despite striking differences between the two substances, the observations indicate a close relationship.

Also included in this report are some biochemical and physiological properties of spca in addition to those already reported.

\section{MATERIALS AND ANALYTICAL METHODS}

One unit of spca is defined as that amount of material which, when added in a volume of $0.05 \mathrm{ml}$. to $0.05 \mathrm{ml}$. of normal oxalated human plasma diluted in $0.9 \mathrm{ml}$. of prothrombin-free plasma, will double the prothrombic activity (accelerate prothrombin conversion) of the normal plasma as measured by a modified one-stage method of prothrombin determination (7). The prothrombin-free plasma was prepared by adsorbing normal plasma with BaSO, (hereafter called BaSO, plasma). Prothrombic activity was calculated by interpolation of the observed prothrombin time of the mixture on a standardization curve derived from the prothrombin times of normal plasma similarly diluted with varying amounts of $\mathrm{BaSO}$. plasma. Rabbit brain (Difco) provided the source of thromboplastin.

In some experiments prothrombin was also determined by both the orthodox two-stage method of Warner, Brinkhous and Smith (12), and by the modified procedure of Ware and Seegers (13) in which optimal amounts of Ac-globulin are provided. Beef lung thromboplastin (13) was used in the two-stage procedure. 
Spca was obtained from normal human serum. Preparations of beef prothrombin (1000 units per mgm.) and serum Ac-globulin (100 units per mgm.) were kindly provided by Dr. Walter H. Seegers. The Ac-globulin contained $1.3 \mathrm{mgm}$. of prothrombin (1200 units) per 100 mgm. of sample and traces of thrombin.

Human prothrombin was prepared as follows: $\mathrm{BaSO}$ was added to oxalated human plasma ( $25 \mathrm{mgm}$. per $\mathrm{ml}$.). The mixture was shaken frequently while kept at $37^{\circ} \mathrm{C}$ for 15 minutes, was then centrifuged, and the supernatant was discarded. The sediment was washed three times by resuspending in acetate buffer $(0.02 \mathrm{M}, \mathrm{pH} 5.2)$. It was then dispersed twice in a $5 \%$ solution of sodium citrate in physiological saline, the total volume equalling the original plasma. The mixtures were agitated for 10 minutes, and then centrifuged. The supernatant, containing most of the plasma prothrombic activity, was dialyzed overnight against distilled water at $6^{\circ} \mathrm{C}$, lyophilized and then stored at $45^{\circ} \mathrm{C}$ until used. Under these conditions the preparation remained fully potent for at least two months. For some experiments the prothrombin used was the dialyzed material heated at $56^{\circ} \mathrm{C}$ for five minutes and then maintained in the frozen state at $-20^{\circ} \mathrm{C}$ until used. Fractions thus prepared contain approximately 200 units of prothrombin per mgm. of solids, are stable for at least three months, and are only slowly convertible to thrombin by thromboplastin plus calcium in the absence of Ac-globulin.

\section{SEPARATION AND PURIFICATION OF SPCA}

Venous blood was allowed to clot for one hour at room temperature in chemically clean glass containers, and was then centrifuged at $2000 \mathrm{rpm}$ for 20 minutes. The supernatant sera, which were separated and pooled, contained 15-20 units of spca per $\mathrm{ml}$. and $0-18 \%$ prothrombic activity 2 (one-stage).

To the pooled serum $\left(700 \mathrm{ml}\right.$.) was added $\mathrm{BaSO}_{4}$ (C.P.), $20 \mathrm{mgm}$. per $\mathrm{ml}$. The mixture was shaken, incubated and frequently agitated at $37^{\circ} \mathrm{C}$ for 20 minutes, and then centrifuged at $3000 \mathrm{rpm}$ for 30 minutes. The supernatant, containing $30-40 \%$ of the original spca activity and most of the prothrombic activity, was discarded. ${ }^{3}$ The sediment was washed by dispersion in small volumes of $0.02 \mathrm{M}$ acetate buffer ( $\mathrm{pH} 5.2$ ) until the final washing (usually the third) gave no turbidity upon the addition of 3\% sulfosalicylic acid. The washings were devoid of spca. To the washed BaSO, was added $25 \mathrm{ml}$. of $5 \%$ sodium citrate in physiological saline. The mixture was agitated for 20 minutes, and then centrifuged at $3000 \mathrm{rpm}$ for 30 minutes.

2 This does not necessarily mean $0-18 \%$ prothrombin since one-stage serum prothrombic activity may reflect both prothrombin and spca (14).

3 Although larger proportions of $\mathrm{BaSO}$, remove more spca, they simultaneously absorb more prothrombin and other proteins which make subsequent purification more difficult.
The supernatant was separated, and the $\mathrm{BaSO}$, was again eluted with the same amount of citrate-saline. The eluates were dialyzed separately (for convenience), each against 2 liters of distilled water, at $6^{\circ} \mathrm{C}$ for 18 hours with three changes in the water at six hour intervals. No losses in spca were thus incurred. The dialyzed solutions (48 and $51 \mathrm{ml}$. respectively) were lyophilized, yielding altogether $125 \mathrm{mgm}$. of a light yellow powder, which, except for a very small portion, was readily soluble in water. Preparations thus obtained contain 0.5-1.0 units of spca per microgram of $\mathrm{N}$.

The material was dissolved in $10 \mathrm{ml}$. of $\mathrm{H}_{2} \mathrm{O}$, and the insoluble material, which was inert, was removed. To the solution was added solid $\left(\mathrm{NH}_{4}\right)_{2} \mathrm{SO}_{4}$ till $90 \%$ saturation. A white flocculent precipitate resulted which did not sediment completely at $2000 \mathrm{rpm}$. The supernatant suspension, transferred to a multispeed attachment of the International Centrifuge, was then effectively centrifuged for 30 minutes at $15,000 \mathrm{rpm}(19300 \mathrm{G})$ at $6^{\circ} \mathrm{C}$. Occasionally in other runs even at this gravitational force the material failed to sediment. In such instances reducing the concentration of $\left(\mathrm{NH}_{4}\right)_{2} \mathrm{SO}_{4}(2-5 \%)$ by addition of a small amount of $\mathrm{H}_{2} \mathrm{O}$ permitted sedimentation.

The sediments from both low and high speed centrifugation dissolved readily in $\mathrm{H}_{2} \mathrm{O}$. Over $80 \%$ of the spca activity was in the sediment obtained at high speed. The "low-speed" material was reprecipitated with $\left(\mathrm{NH}_{4}\right)_{2}$ SO. (90\% saturation) and the mixture recentrifuged with recovery of considerable activity from its sediment obtained at the high centrifugal speed.

The "high-speed" sediments were pooled and dissolved in $5 \mathrm{ml}$. of $\mathrm{H}_{2} \mathrm{O}$ and dialyzed against 2 liters of $\mathrm{H}_{2} \mathrm{O}$ at $6^{\circ} \mathrm{C}$ for six hours. The water was changed, dialysis was continued for another 12 hours, and the light, white flocculent precipitate which formed was separated. It contained less than $20 \%$ of the spca activity, which was recovered by washing with distilled water. The supernatant solution, together with these washings, was lyophilized, yielding $15 \mathrm{mgm}$. of a white powder only slightly soluble in water. The suspension in water $(1.0 \mathrm{mgm}$. per ml.) gave a $\mathrm{pH}$ of 4.2. Solution occurred when the $\mathrm{pH}$ was raised to 6.6 by adding two drops of imidazole buffer ( $\mathrm{pH} \mathrm{7.3)} \mathrm{to} 5 \mathrm{ml}$. of suspension.

The final product contained $16 \% \mathrm{~N}$, and had an spca activity of 5 units per microgram $\mathrm{N}$ or 800 units per mgm. of solid. The total yield was approximately $57 \%$. The material was free of prothrombin and thrombin.

\section{COMPARATIVE STUDY OF SPCA AND AC-GLOBULIN}

\section{Preliminary remarks and definitions}

Before the results of a comparative study of spca and Ac-globulin are presented with the purpose of establishing their relationship, certain basic considerations and definitions are essential. Clearly, an adequate explanation of the "autocatalytic" mechanism of thrombin formation requires demonstration of an agent which arises as 
a consequence of the coagulation process and which is capable of accelerating prothrombin conversion. Its effect must be over and above whatever accelerating effects are produced by plasma factor(s) which are accessory agents important in prothrombin conversion.

The rapid evolution of thrombin from purified prothrombin requires such accessory agents. Therefore, the accelerating effect on purified prothrombin of a given biological preparation derived either from plasma or serum does not necessarily indicate the presence of the "autocatalytic" agent unless optimal amounts of the plasma factors are already assured in the test system.

Some consideration must also be given to the concentration of these factors in the plasma of different species. Human prothrombin diluted in bovine (15) or rabbit or dog prothrombin-free plasma (16) is convertible to thrombin more rapidly than when diluted in human prothrombinfree plasma. This is probably referable to a greater concentration of an accessory prothrombin-converting factor in the plasma of these species than obtains in man. We have evidence that bovine plasma contains such a factor in amounts at least ten-fold that in humans (15). Furthermore, substantial amounts of this entity are demonstrable in bovine serum. Accordingly, fractions derived from bovine serum may show clot-promoting effects on human plasma which may erroneously be interpreted as "autocatalytic" accelerator activity whereas actually they may be inert on the evolution of thrombin in bovine plasma which already has this factor in optimal amounts.

It is, therefore, emphasized that the true "autocatalytic accelerator" of prothrombin conversion must $a$ priori be an agent which arises during the coagulation reaction and which is capable of accelerating prothrombin conversion in the plasma of the homologous species.

On the basis of these considerations, and since spca and Ac-globulin fractions are admittedly impure, we feel that for the present one should speak only in terms of "spca activity" or "Ac-globulin activity" before conclusively attributing these activities to individual distinct components.

Spca is measured by its acceleration of thrombin evolution from the prothrombin present in a mixture which also contains prothrombin-free normal plasma, thromboplastin and calcium (7).
The method consists of a modified one-stage procedure for the determination of prothrombin. Acceleration of prothrombin conversion under these conditions is, for the purposes of this paper, defined as "spca activity."

Ac-globulin is active in the two-stage system (13), accelerating thrombin evolution from purified prothrombin as well as increasing the yield of thrombin $(1-4)$. The essential difference between this system and the modified one-stage procedure is that the two-stage system does not contain prothrombin-free plasma. Again for the purposes of this paper, two-stage acceleration of thrombin evolution is defined as "Ac-globulin activity."

\section{Effect of spca and Ac-globulin on prothrombin conversion}

Data have already been presented regarding the velocity of prothrombin conversion in plasmaserum mixtures containing various concentrations of prothrombin and spca (7). Purified preparations of spca and human prothrombin were mixed in varying proportions in a system containing prothrombin-free plasma. The effect on the velocity of prothrombin conversion is shown in Figure 1.

In view of the marked effect of spca on the velocity of one-stage prothrombin conversion (and, as will be seen later, on the coagulation of whole blood or plasma) it was striking to find that spca was practically inert on purified human or bovine

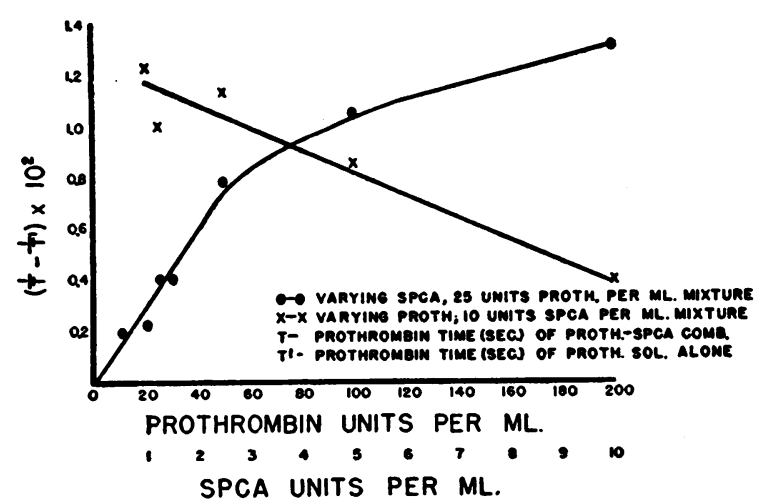

Fig. 1. EFFect of SPCA on Velocity of Thrombin Evolution from Purified Human Prothrombin in the One-Stage System

Clotting mixtures contained prothrombin and spca, in amounts indicated, in a $90 \%$ solution of $\mathrm{BaSO}$. plasma. 
prothrombin in the two-stage system (Figures 2, $2 a)$. Both the velocity of thrombin formation and the amount evolved were relatively unaffected by the addition of spca to a mixture of prothrombin, thromboplastin and calcium. It is thus concluded that human spca lacked Ac-globulin activity. $\mathrm{Hu}$ man serum tested $1 \frac{1}{2}$ hours after blood has been shed similarly contains negligible Ac-globulin activity (Figure 3 ), confirming the findings of Murphy and Seegers (17).

As mentioned above, the essential difference be-

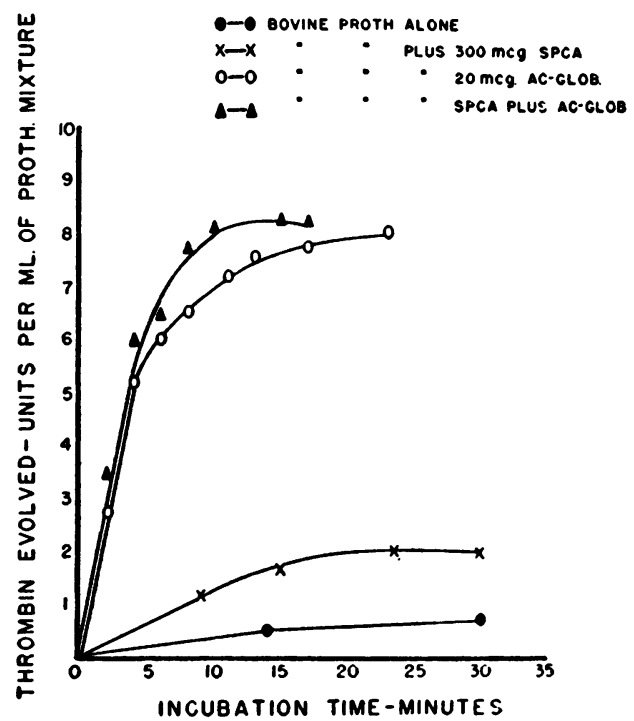

Fig. 2. EfFect of SPCA and Ac-Globulin on Conversion of Purified Bovine Prothrombin in Two-Stage SySTEM

Prothrombin mixture contained $50 \mathrm{mcg}$. of prothrombin per $\mathrm{ml}$. in $0.9 \%$ sodium chloride solution to which was added Ac-globulin and/or spca as indicated. To $1.0 \mathrm{ml}$. of this mixture were added $3.0 \mathrm{ml}$. of a reaction mixture comprising $1.0 \mathrm{ml}$. beef lung thromboplastin extract, 0.67 ml. of $0.025 \mathrm{M} \mathrm{CaCl}_{2}, 0.17 \mathrm{ml}$. of imidazole buffer and 1.17 $\mathrm{ml}$. of $0.9 \%$ sodium chloride solution. The evolved thrombin in the ensuing mixture, kept at room temperature, was measured at specified intervals by adding $0.4 \mathrm{ml}$. to $0.1 \mathrm{ml}$. of a $1.0 \%$ solution of fibrinogen (Fraction I Armour) and determining the clotting time. The observed clotting times were converted into units of thrombin by interpolation from a standardization curve derived from clotting times obtained by adding variable amounts of bovine thrombin (Parke, Davis Topical Thrombin) in the same reaction mixture to the standard fibrinogen solution. One unit of thrombin was considered that amount necessairy to produce clotting in 15 seconds. Only those clotting times between 12 and 45 seconds were considered valid for calculation. This essentially is the twostage method for prothrombin determination (13).

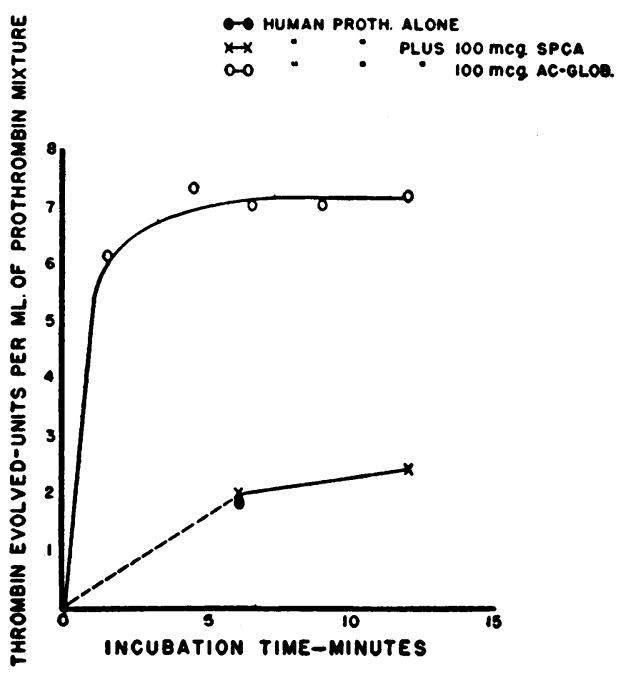

Fig. 2a. Effect of SPCA AND Ac-Globulin on TwoStage Conversion of Purified Human Prothrombin

Prothrombin mixture contained a fixed amount of human prothrombin obtained by citrate elution of the $\mathrm{BaSO}_{4}$ adsorbate of human plasma. 2.

Procedure of thrombin determination same as for Figure

tween the two-stage system in which spca is inert and the one-stage system where spca is active is that the latter contains non-prothrombin plasma factors. This suggests that spca requires for its

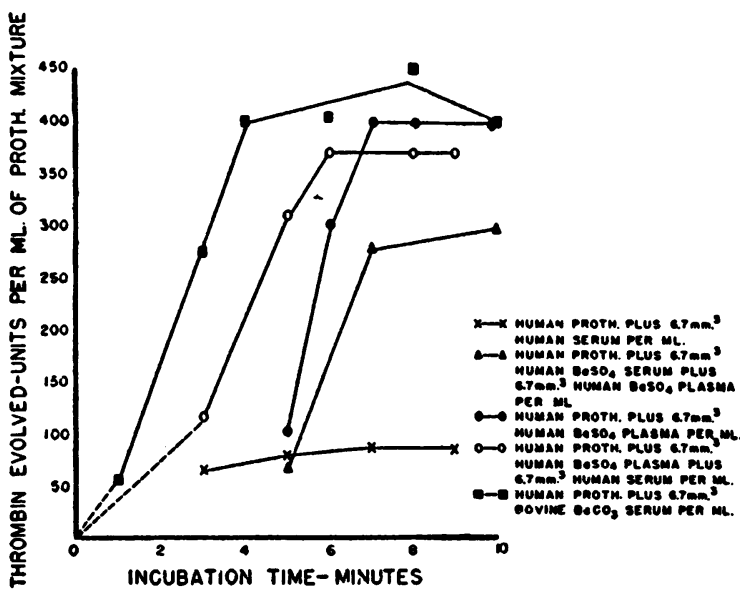

Fig. 3. Comparative Effect of Human Serum (Two Hours Old), Human Prothrombin-Free Plasma, and Bovine BaCO s Serum (40 mga. BaCO a PER ML.) on Evolution of Thrombin from Purified Human ProTHROMBIN IN ISOLATED SYSTEM

Procedure of thrombin determination same as for Figure 2. Human prothrombin was obtained by citrate elution of the $\mathrm{BaSO}_{4}$ adsorbate of human plasma. The material was heated for five minutes at $56^{\circ} \mathrm{C}$ to inactivate possible Ac-globulin contaminant. 
activity a non-prothrombin plasma factor important in prothrombin conversion. Human serum, tested two hours after obtaining the blood, was mixed with human prothrombin-free $\left(\mathrm{BaSO}_{4}\right)$ plasma. The mixture accelerated prothrombin conversion in the two-stage system more than the $\mathrm{BaSO}_{4}$ plasma alone (Figure 3 ). By itself the serum had negligible effect. In contrast, bovine serum adsorbed with $\mathrm{BaCO}_{3}$ according to the technique of Ware and Seegers (13) was markedly active, even more than human plasma plus human serum.

This increment in accelerating effect induced by the added human serum was obviated by adsorbing the serum with $\mathrm{BaSO}_{4}$ (50 mgm. per ml.). Indeed, the combination of $\mathrm{BaSO}_{4}$ plasma with $\mathrm{BaSO}_{4}$ serum reduced not only the velocity but also the total yield of thrombin in contrast to the results obtained with $\mathrm{BaSO}_{4}$ plasma alone or with $\mathrm{BaSO}_{4}$ plasma with whole serum.

From the data (Figure 3 ) recorded above, it therefore appears that spca contributed some accelerating activity also in the two-stage system if non-prothrombin plasma factors are provided. It also appears that this factor(s) was present in the Ac-globulin preparation (Figure 2).

\section{TABLE I}

Effect of spca on velocity of prothrombin conversion in onestage system. Indication of latent period required for full spca activity

Prothrombin mixture comprised $0.05 \mathrm{ml}$. normal plasma, $0.05 \mathrm{ml}$. of spca in physiological saline, and $0.95 \mathrm{ml}$. $\mathrm{BaSO}_{4}$ normal plasma

\begin{tabular}{|c|c|c|c|}
\hline & Conditions & $\underset{\text { time }}{\text { Prothrombin }}$ & $\begin{array}{c}\text { Prothrombic } \\
\text { activity }\end{array}$ \\
\hline \multirow[t]{3}{*}{ Exp't 1} & No spca & $\begin{array}{c}\text { sec. } \\
43.0\end{array}$ & $\begin{array}{c}\%^{*} \\
110\end{array}$ \\
\hline & & 36.0 & 156 \\
\hline & $\begin{array}{l}1 \text { min. after mixing } \\
2 \text { min. after mixing } \\
3 \text { min. after mixing } \\
5 \text { min. after mixing }\end{array}$ & $\begin{array}{l}29.2 \\
28.8 \\
28.2 \\
28.6\end{array}$ & $\begin{array}{l}220 \\
224 \\
234 \\
230\end{array}$ \\
\hline \multirow[t]{2}{*}{ Exp't 2} & $\begin{array}{l}\text { No spca } \\
1 \text { unit spca }\end{array}$ & & 66 \\
\hline & $\begin{array}{l}\text { Tested promptly } \\
1 \text { min. after mixing } \\
2 \text { min. after mixing } \\
3 \text { min. after mixing } \\
4 \text { min. after mixing } \\
5 \text { min. af ter mixing }\end{array}$ & $\begin{array}{l}33.0 \\
30.6 \\
30.0 \\
29.2 \\
27.0 \\
27.5\end{array}$ & $\begin{array}{l}116 \\
134 \\
140 \\
148 \\
176 \\
170\end{array}$ \\
\hline
\end{tabular}

* Corrected for the 20 -fold dilution of the normal plasma. $100 \%$ represents the prothrombic activity of whole normal plasma.
TABLE II

Effect of Ac-globulin on one-stage prothrombin conversion Exp't 1. Each ml. of prothrombin mixture contained $\mathbf{0 . 0 5}$ ml. normal human plasma, $0.05 \mathrm{ml}$. physiological saline plus serum Ac-globulin in amounts indicated, and $0.90 \mathrm{ml}$. normal human $\mathrm{BaSO}$, plasma

$\begin{array}{rcc}\begin{array}{c}\text { Ac-globulin } \\ \text { mcg. }\end{array} & \begin{array}{c}\text { Time } \\ \text { sec. }\end{array} & \begin{array}{c}\text { Prothrombin } \\ \text { Activity } \\ \%^{*}\end{array} \\ 0 & 34 & 100 \\ 2 & 34 & 100 \\ 10 & 25 & 190 \\ 100 & 17 & 600+\end{array}$

Exp't 2. $0.10 \mathrm{ml}$. normal plasma, $0.10 \mathrm{ml}$. saline plus Ac-globulin, and $0.80 \mathrm{ml}$. BaSO plasma

$\begin{array}{rlr}0 & 25.6 & 90 \\ 6 & 25.6 & 90 \\ 10 & 21 & 150 \\ 300 & 13 & 1000+\end{array}$

* Corrected for the dilution of the normal plasma.

$100 \%$ represents the prothrombic activity of normal plasma.

That spca requires a plasma factor for its activity is indicated by additional experiments. Spca is measured by mixing one part of spca, one part of normal plasma or prothrombin preparations and 18 parts of prothrombin-free plasma; the prothrombin time of the mixture is then determined in the usual manner. With purified preparations of spca full activity did not appear until a certain interval (approximately one to five minutes) had elapsed after the test mixture was prepared (Table I). This phenomenon, which could readily escape detection, suggests interaction between spca and another component in the system.

The concept that an additional factor, present in plasma, is required for spca is further substantiated by experiments on aged plasma (see later) on which purified spca is similarly inert.

In contrast to the inactivity. of spca in the twostage system the Ac-globulin preparation was extremely active, accelerating thrombin evolution and increasing thrombin yield from human as well as bovine prothrombin (Figures 2, 2a).

The question arose as to whether the Ac-globulin would also accelerate prothrombin conversion in the one-stage system (would show spca activity). Accordingly, it was tested on human plasma diluted in human $\mathrm{BaSO}_{4}$ plasma. The prothrombin time of the mixture was shortened, indicating accelerated evolution of thrombin from the human prothrombin (Table II). Thus, whereas purified spca shows spca activity but no Ac-globulin activity, the preparation of bovine serum Ac-globu- 


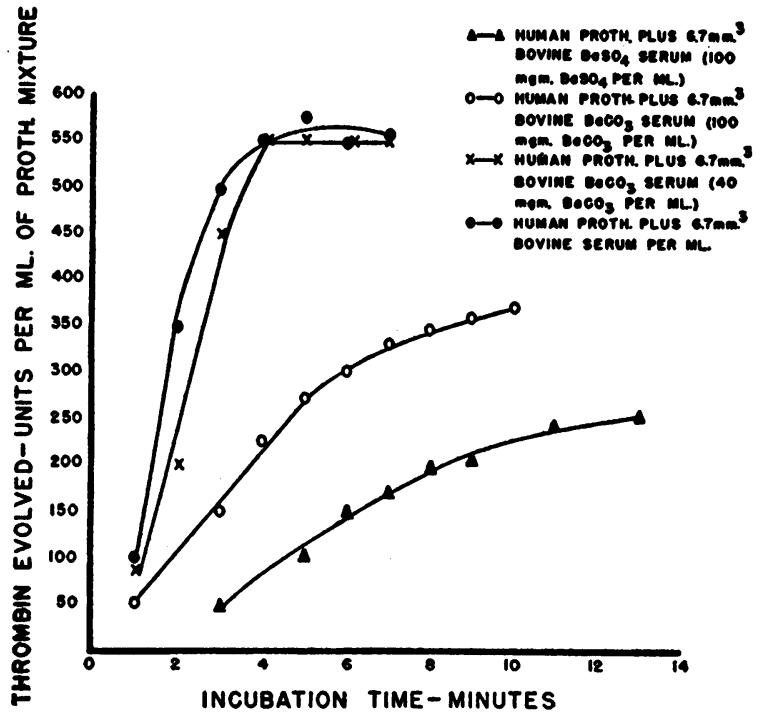

Fig. 4. EFfects of Adsorption with BaSO AND $\mathrm{BaCO}_{8}$ on Ac-Globulin Activity of Bovine Serum on Purified Human Prothrombin

Procedure of thrombin determination same as for Figure 2. Human prothrombin was obtained by citrate elution of the $\mathrm{BaSO}_{4}$ adsorbate of human plasma. Fresh bovine serum was obtained at the slaughter house, then frozen, and tested 24 hours later. It contained 32 units of prothrombin per $\mathrm{ml}$. The adsorbed sera contained only traces of prothrombin.

lin showed both Ac-globulin and spca activity. The Ac-globulin, however, showed only oneeighth the spca activity of the purest spca fraction.

Other observations on Ac-globulin are noteworthy. Ware and Seegers (13) report that the same results are obtained regarding the prothrombin values for human (or bovine) plasma determined by the two-stage method whether the system is or is not supplemented by additional Ac-globulin. We have confirmed this: both the velocity of prothrombin conversion and the yield of thrombin evolved from the prothrombin in human plasma were not affected by the addition either of purified serum Ac-globulin, or of beef serum containing "Ac-globulin" (Figure 4).4 On purified human (or bovine) prothrombin, on the other hand, Ac-globulin is highly active.

This may be interpreted as indicating that hu-

4 Occasionally plasma from an apparently normal individual is encountered in which prothrombin conversion and thrombin yield are increased by supplements of beef serum (adsorbed with $\mathrm{BaCO}_{3}$ according to the modified two-stage method). man plasma contains sufficient plasma Ac-globulin to assure most rapid and maximal conversion of its prothrombin to thrombin. Against this is the report of Murphy and Seegers (17) that in human plasma the ratio of plasma Ac-globulin to prothrombin is fairly critical. One would therefore expect on this basis alone that supplementing human plasma with Ac-globulin should result in faster thrombin evolution in the two-stage as well as the one-stage system. Furthermore, it is claimed that serum Ac-globulin is more active than plasma Ac-globulin. Accordingly, additions of serum Ac-globulin to human or even bovine plasma should give faster two-stage prothrombin conversion. Why it does not remains obscure.

We have seen how the preparation of Ac-globulin exhibited spca activity on human prothrombin in a human-diluted system. It was important to know whether it would also be active on bovine prothrombin in an all bovine medium. Unfortunately, this experiment could not be carried out with the Ac-globulin fraction due to shortage of material. Tests were, however, performed with beef serum, rich in Ac-globulin. It is clearly evident (Table III) that beef serum accelerates prothrombin conversion in beef plasma thus diluted, although the effect is not as marked as the clotpromoting activity of human serum. This is also true in the human-diluted system. It may, therefore, be concluded that beef serum shows Ac-glob-

\section{TABLE III}

Spca activity on bovine plasma of bovine compared with human serum*

Each $\mathrm{ml}$. of prothrombin mixture contained $0.10 \mathrm{ml}$. of bovine plasma, $0.05 \mathrm{ml}$. of saline or serum (human or bovine) and as diluent $0.85 \mathrm{ml}$. of $\mathrm{BaSO}_{4} \dagger$ plasma (human or bovine).

$$
\text { Serum Mixture Diluent } \quad \begin{gathered}
\text { Prothrombin } \\
\text { time }
\end{gathered}
$$

$\begin{array}{lll}\text { None } & \text { Bovine } & \text { sec. } \\ \text { Bovine } & \text { Bovine } & 62 \\ \text { Human } & \text { Bovine } & 41 \\ \text { None } & \text { Human } & 23 \\ \text { Bovine } & \text { Human } & 80 \\ \text { Human } & \text { Human } & 45 \\ \text { Bovine BaSO } † & \text { Bovine } & 28 \\ \text { Human BaSO } \dagger & \text { Bovine } & 62 \\ \text { Bovine BaSO } \dagger & \text { Human } & 59 \\ \text { Human BaSO } \dagger & \text { Human } & 84 \\ \end{array}$

* Blood allowed to clot for one hour. Sera separated, incubated for $15 \mathrm{~min}$. at $37^{\circ} \mathrm{C}$. One part saline added to four parts serum.

$t$ All $\mathrm{BaSO}_{4}$ plasma or sera obtained with $100 \mathrm{mgm}$. $\mathrm{BaSO}_{4}$ per ml. except human $\mathrm{BaSO}_{4}$ serum which was prepared with $50 \mathrm{mgm}$. per $\mathrm{ml}$. This amount removes spca quantitatively from human serum. 
TABLE IV

Spca activity on human plasma of bovine compared with human serum*

Each ml. of prothrombin mixture contained $0.05 \mathrm{ml}$. of human plasma, $0.05 \mathrm{ml}$. of saline or serum (human or bovine), and as diluent $0.90 \mathrm{ml}$. of $\mathrm{BaSO}_{4} \dagger$ plasma (human or bovine).

\begin{tabular}{l|l|c|c}
\hline \multicolumn{2}{c|}{ Mixture } & \multicolumn{2}{c}{ Prothrombin } \\
\cline { 2 - 4 } Serum & \multicolumn{1}{c}{ Diluent } & Time & Activity \\
\hline & & sec. & $\%$ \\
None & Human & 36 & 80 \\
Human & Human & 21 & 200 \\
Human BaSO4 & Human & 35 & 84 \\
Bovine & Human & 28 & 126 \\
Bovine BaSO4 & Human & 33 & 95 \\
None & Human (0.05 ml. BaSO4 & 31 & 100 \\
& bovine plasma added) & & \\
\hline None & Bovine & 26 & \\
Human & Bovine & 20 & \\
Human BaSO4 & Bovine & 23 & \\
Bovine & Bovine & 25 & \\
Bovine BaSO4 & Bovine & \\
\hline
\end{tabular}

* Blood allowed to clot for one hour. Sera separated, incubated for $15 \mathrm{~min}$. at $37^{\circ} \mathrm{C}$. One part saline added to four parts serum.

$t$ All $\mathrm{BaSO}_{4}$ plasma or sera were obtained with $100 \mathrm{mgm}$. $\mathrm{BaSO}$, per ml. except human $\mathrm{BaSO}_{4}$ serum which was obtained with $50 \mathrm{mgm}$. per $\mathrm{ml}$. (this amount removes spca quantitatively from human serum).

$\ddagger$ Corrected for the 20 -fold dilution of the normal human plasma.

ulin activity, and also spca activity on prothrombin conversion in bovine- as well as human-diluted systems.

Treating beef serum with $\mathrm{BaSO}_{4}$ removes practically all of the spca activity when tested on bovine or human plasma in bovine diluent. The same results are obtained with human serum, whether tested in an all bovine or all human system.

On the other hand, somewhat different results are obtained when bovine $\mathrm{BaSO}_{4}$ serum is tested on human plasma in a human diluent (Table IV). Under these conditions also whole beef serum shows considerable spca activity. The $\mathrm{BaSO}_{4}$ treated serum, however, exhibits $30-50 \%$ of the activity of the parent serum whereas the same $\mathrm{BaSO}_{4}$ serum is inert on human plasma in a bovine diluent.

The question arises whether this might be referable to a non-specific heterologous species effect of a plasma constituent. Substantial amounts of such a substance, present in larger concentration in beef than in human plasma, may have been carried over unaltered to the bovine serum which, when added to an all human system critical in this clotting factor, might have accelerated clotting, thus exhibiting "spca activity." If so, bovine plasma treated with $\mathrm{BaSO}_{4}$ should show at least comparable, if not more, clot-promoting effect under the same conditions. It is evident (Table IV) that bovine $\mathrm{BaSO}_{4}$ plasma added to human plasma diluted in human $\mathrm{BaSO}_{4}$ plasma shows "spca activity," i.e., accelerates prothrombin conversion, and to a greater extent than beef $\mathrm{BaSO}_{4}$ serum which, to repeat, is inert against bovine or human prothrombin diluted in bovine prothrombin-free plasma. It is, therefore, concluded that the "spca activity" of the beef $\mathrm{BaSO}_{4}$ serum is referable to an accessory prothrombin-converting component in beef plasma which is not adsorbed by $\mathrm{BaSO}_{4}$, which is carried over into the beef serum and which is present in critically low concentrations in the blood of man. It is not a clot-promoting agent arising as a consequence of coagulation since it has no effect on thrombin evolution in the bovine system.

\section{Adsorbability of spca and Ac-globulin}

Spca is adsorbed from human serum by $\mathrm{BaSO}_{4}$ and $\mathrm{BaCO}_{3}$. Twenty-five mgm. of $\mathrm{BaSO}_{4}$ per $\mathrm{ml}$. of serum remove approximately $80-90 \%$ of the activity; more of the adsorbing agent removes it completely. One hundred mgm. of $\mathrm{BaCO}_{3}$ per $\mathrm{ml}$. adsorbs all of the spca. As indicated above, spca activity can similarly be adsorbed from bovine serum. The adsorptions were carried out at $37^{\circ} \mathrm{C}$ for 15 minutes with frequent agitation of the mixtures.

The question arises as to whether Ac-globulin behaves differently. Ware and Seegers remove residual prothrombin from bovine serum by $\mathrm{BaCO}_{3}$ (13). The adsorbed serum is said to retain full Ac-globulin activity, and consequently is recommended as a potent source of Ac-globulin for twostage prothrombin determinations.

Our observations indicate that "Ac-globulin activity" is partly removed from serum by $\mathrm{BaSO}_{4}$ or $\mathrm{BaCO}_{3}$. Aliquots of fresh beef serum were adsorbed with $\mathrm{BaCO}_{3}$ ( 40 or $100 \mathrm{mgm}$. per ml.) or $\mathrm{BaSO}_{4}(100 \mathrm{mgm}$.). Considerable activity was lost with the larger proportions of adsorbing agents when tested on human prothrombin in the two-stage system (Figure 4). The residual activity could also have been due to the unconsumed 
(and unadsorbed) plasma prothrombin converting accessory factor mentioned above.

\section{Resume}

Human spca, purified or in serum, accelerates the conversion of bovine or human prothrombin to thrombin in the one-stage system, whereas in the two-stage system it is inert. In contrast, the bovine serum Ac-globulin fraction was active in both systems. The essential difference between the systems is that in the one-stage procedure plasma factors important in prothrombin conversion are amply provided by a prothrombin-free plasma diluent whereas in the two-stage system they are absent when purified prothrombin is used, or they may be critically low when whole plasma is tested.

$\mathrm{BaSO}_{4}$ or $\mathrm{BaCO}_{3}$ removes all the spca activity from human serum, and $\mathrm{BaSO}_{4}$ removes all the spca activity from bovine serum when tested on bovine or human prothrombin diluted in bovine media. The adsorbed bovine serum simultaneously exhibits much less "Ac-globulin activity" than the unadsorbed serum on purified prothrombin. When tested on human prothrombin diluted in human media, adsorbed bovine serum retains $30-50 \%$ of its "spca activity," a non-specific ${ }^{5}$ clotpromoting effect indistinguishable from that of $\mathrm{BaSO}_{4}$ adsorbed bovine plasma.

\section{Elution of spca from $\mathrm{BaSO}_{4}$}

We have seen how spca is adsorbed from bovine or human serum by $\mathrm{BaSO}_{4}$. It can be eluted from this adsorbing agent by solutions of sodium citrate (5\% in physiological saline). The material can similarly be adsorbed and eluted from partially purified fractions, and in this way can be further purified. Concentration of spca can be achieved by using small volumes of eluting agent. It should be noted that fractions thus derived from bovine serum exhibit both spca and Ac-globulin activity; the latter, as will be evident later, is labile. It is of interest that prothrombin, also, can be adsorbed by $\mathrm{BaSO}_{4}$ and eluted with sodium citrate. These properties permit separation and purification of this substance by a simple procedure.

\footnotetext{
${ }^{5}$ Non-specific in the sense that the effect is not due to a factor evolving during coagulation but to a plasma component carried over unaffected into the serum.
}

\section{Spca and Ac-globulin activity on prothrombin conversion in aged plasma}

As plasma ages the velocity with which its prothrombin can be converted to thrombin becomes retarded, due to deterioration of a labile plasma component (Labile Factor). The defect can be rectified by the addition of fresh prothrombinfree plasma $(18,19)$.

It has been reported earlier that under certain conditions, human serum, although rich in spca, has little effect in reducing the elevated prothrombin time of aged plasma (7). Purified spca also is practically inert in this respect; aged plasma with a prothrombin time of 59 seconds was unaffected by the addition of 160 units of spca per $\mathrm{ml}$. However, when fresh $\mathrm{BaSO}_{4}$ plasma is added to such a mixture, the prothrombin time is lowered and full spca activity is demonstrable. This indicates that for the accelerating effects of spca a non-prothrombin factor is required which is labile, is present in normal plasma, is decreased or absent in human serum, and which is not adsorbed by $\mathrm{BaSO}_{4}$.

The Ac-globulin preparation, on the other hand, accelerated prothrombin conversion in aged plasma; a 33-second prothrombin time of stored human plasma was reduced to 11 seconds by the addition of $200 \mathrm{mcg}$. (micrograms) of Ac-globulin per $\mathrm{ml}$. In this respect its activity was labile. Incubation or aging of the fraction resulted in marked destruction of its activity (see below). Nevertheless, when fresh prothrombin-free plasma was provided to a mixture of aged plasma and "deteriorated" Ac-globulin, the clot-promoting action of the Ac-globulin was completely restored. In other words, it still exhibited full spca activity.

Additional experiments were performed: Acglobulin was added to fresh human plasma (3.3 mgm. per ml.). As was expected, the mixture showed faster prothrombin conversion (prothrombin time-10 seconds) than the plasma alone (15 seconds.). During storage, however, at $4-5^{\circ} \mathrm{C}$ the prothrombin time of the mixture increased progressively until after 14 days the prothrombin time was 32 seconds. When at this point the mixture was supplemented with prothrombin-free fresh plasma, the full accelerating effect of the Ac-globulin was again observed. 
Thus, whereas spca is inert on whole stored plasma but active when the stored plasma is admixed with fresh prothrombin-free plasma, the preparation of serum Ac-globulin was active on whole stored plasma, it lost this activity on incubation or aging, but the "deteriorated" material was still active on stored plasma supplemented with fresh prothrombin-free plasma. Also, the incubated or aged material had simultaneously lost its Ac-globulin activity (see below), which is in agreement with the observations of Ware and Seegers (4). The "deteriorated" Ac-globulin was now indistinguishable from spca.

\section{Stability of spca and Ac-globulin}

The stability of spca in serum at various temperatures has been described previously $(6,7)$. Experiments with the purified preparation were carried out as follows : an $0.1 \%$ solution was made in water containing one drop of the imidazole buffer ( $\mathrm{pH} 7.3$ per $3 \mathrm{ml}$.). A portion, diluted 1-2 with saline, was incubated at $37^{\circ} \mathrm{C}$ for five hours. No change in activity occurred. At $4-5^{\circ} \mathrm{C}$ full activity was preserved for at least six weeks.

The Ac-globulin activity of plasma or serum or of purified fractions appears to be much more labile. According to Ware and Seegers (4) about half is destroyed in 30 minutes at $37^{\circ} \mathrm{C}$. In human and dog serum it is described as being very labile, virtually disappearing within 30 minutes after coagulation (17). It is also relatively labile in human plasma (20).

Our studies show somewhat divergent results : in some respects the Ac-globulin was capable of reducing the elevated prothrombin time (accelerating prothrombin conversion) in aged plasma. Incubating the Ac-globulin solution for five hours at $37^{\circ} \mathrm{C}$ results in considerable inactivation of this property. Also, aging Ac-globulin solution at $4-5^{\circ} \mathrm{C}$ for two weeks decreases its restorative ability, and incubating the aged Ac-globulin solution at $37^{\circ} \mathrm{C}$ for an additional $41 / 2$ hours renders it completely inert on stored plasma. Yet, the aged and incubated material shows full spca activity. It therefore appears that the Ac-globulin fraction contained at least two entities: one which is stable to aging and incubation, and the other labile under these conditions.

\section{Resume}

Human serum has spca activity but is devoid of Ac-globulin activity. The spca is adsorbable by $\mathrm{BaCO}_{3}$ or by $\mathrm{BaSO}_{4}$ from which it can be eluted by solutions of citrate. Spca, both in purified form or in its native state in serum, is relatively stable.

Bovine serum shows both spca and Ac-globulin activity. Absorption with $\mathrm{BaSO}_{4}$ or $\mathrm{BaCO}_{3}$ removes the spca activity (on bovine or human prothrombin in a bovine medium) completely, Acglobulin activity (on purified prothrombin) partly. The eluate from the $\mathrm{BaSO}_{4}$ adsorbate of bovine serum shows both spca and Ac-globulin activity. The latter is labile.

Spca is inert on aged plasma in which the Labile Factor of prothrombin conversion has deteriorated. In contrast, the Ac-globulin preparation accelerated prothrombin conversion in aged plasma. In this respect, also, its activity was labile. The deteriorated material was, however, just as active as fresh material in accelerating the prothrombin conversion of aged plasma when fresh prothrombin-free plasma was supplemented to the system. Under the same conditions spca also is active. Thus, spca and "deteriorated" Ac-globulin are indistinguishable, both showing spca activity on prothrombin in a system containing also non-prothrombin factors present in fresh plasma.

"Deteriorated" Ac-globulin is inert against purified prothrombin in the two-stage system (is devoid of Ac-globulin activity). Nevertheless, it has full spca activity. Accordingly, it is concluded that the Ac-globulin fraction contained at least two entities: one labile (the Labile Factor) and the other stable (spca). Ac-globulin activity is related particularly to the former, perhaps to both; spca activity is referable to the latter.

\section{Effect of spca and Ac-globulin on blood coagula- tion}

If spca or Ac-globulin were true "autocatalytic" prothrombin-conversion accelerators which evolve as a consequence of coagulation, their addition to whole blood should accelerate clotting. This has been borne out in our observations with spca.

Human serum accelerates the coagulation of normal (8) as well as hemophilic blood (21). Purified spca does the same (Table V). Furthermore, associated with the accelerated clotting of 
TABLE V

1. Effect of spca on coagulation of normal and hemophilic blood

\begin{tabular}{|c|c|c|c|c|c|}
\hline \multirow{3}{*}{ Spca added } & \multicolumn{3}{|c|}{ Clotting time $(\min .)^{*}$} & & \\
\hline & \multirow{2}{*}{$\begin{array}{c}\text { Normal } \\
\text { blood }\end{array}$} & \multicolumn{2}{|c|}{ Hemophilic blood } & & \\
\hline & & Subj. 1 & Subj. 2 & & \\
\hline $\begin{array}{c}\text { mcg. per ml. } \\
0 \\
2.6 \\
5.2 \\
10.5 \\
15.6 \\
25.6 \\
50.0\end{array}$ & $\begin{array}{l}\frac{9}{-} \\
\frac{-}{3}\end{array}$ & $\begin{array}{r}43 \\
31 \\
21 \\
12 \\
8 \\
5 \\
-\end{array}$ & $\begin{array}{r}33 \\
26 \\
25 \\
8 \\
7 \\
4 \\
-\end{array}$ & & \\
\hline \multirow{2}{*}{50.0} & & & & \multicolumn{2}{|c|}{ Serum prothrombint } \\
\hline & & & & Subj. 1 & Subj. 2 \\
\hline $\begin{array}{r}0 \\
50\end{array}$ & & $\underset{5}{120+}$ & $\underset{5}{120+}$ & $\begin{array}{r}123 \\
66\end{array}$ & $\begin{array}{l}147 \\
100\end{array}$ \\
\hline
\end{tabular}

2. Effect of spca or Ac-globulin on prothrombin time of whole normal human plasma Material

Normal plasma

Normal plasma plus $0.20 \mathrm{mgm}$. spca per ml.

Normal plasma

Normal plasma plus $3.3 \mathrm{mgm}$. serum Ac-globulin per $\mathrm{ml}$.

* Determined by a modification of the Lee-White method (22).

$t$ Plasma prothrombin on subjects 1 and 2 was 138 and 165 units respectively. Sera separated one hour after coagulation, incubated at $37^{\circ} \mathrm{C}$ for additional 30 minutes, then oxalated and stored at $4-5^{\circ} \mathrm{C}$ overnight till tested. Prothrombin was determined by the modified two-stage method (13).

hemophilic blood was an increase in the amount of prothrombin consumed. It should be reemphasized that the spca contained no thrombin.

Normal plasma also accelerates the coagulation of hemophilic blood; the active agent is antihemophilic globulin (22). This clotting factor, distinct from spca, is a plasma component which is labile (15), is consumed in coagulation (15) and is not adsorbed by $\mathrm{BaSO}_{4}$ (19). That spca acts via a different mechanism from antihemophilic globulin is also suggested by the following observation: 100 mcg. of spca were added to $2 \mathrm{ml}$. of blood obtained from a hemophiliac who had become completely resistant to the clot-accelerating effect of normal plasma; the clotting time was lowered from 125 minutes to 15 minutes.
Spca promotes the coagulation of blood in which the reaction is delayed for other reasons. Clotting proceeds much more slowly in siliconized containers than in glass, due to retarded liberation of thromboplastin. Normal blood, exposed only to apparatus siliconized by the technique of Jaques and his associates (23), clotted in 57 minutes at $37^{\circ} \mathrm{C}$. Under the same conditions $2 \mathrm{ml}$. of blood containing $100 \mathrm{mcg}$. of spca clotted in seven minutes. Here, too, increased prothrombin consumption was observed; residual serum prothrombin (two-stage) was decreased from 150 to 50 units.

A similar experiment was done on heparinized blood. Normal blood containing $2 \mathrm{mcg}$. of heparin (0.26 International Units) per ml. clotted in 23 minutes at $37^{\circ} \mathrm{C}$. In the presence of $50 \mathrm{mcg}$. spca per ml. it clotted in 13 minutes. Blood containing $4 \mathrm{mcg}$. of heparin per $\mathrm{ml}$. clotted in $42 \mathrm{~min}$ utes; with added spca ( 50 mcg.) it clotted in 32 minutes.

Little is known regarding the effect of Ac-globulin on coagulation of whole blood. Our experiments indicate that the Ac-globulin preparation accelerated the coagulation of whole normal human blood. The prothrombin time of whole plasma is also shortened (Table V). It should be noted that the preparation contained traces of thrombin.

Ferguson and Lewis (24) find Ac-globulin inert on hemophilic blood. On the other hand, bovine serum (as well as plasma) accelerates the clotting of hemophilic blood (15). Whether this is due to Ac-globulin, antihemophilic globulin, or to the relatively high concentration in bovine blood of plasma factors important in prothrombin conversion is not clear.

It is well known that trypsin and other proteolytic enzymes may accelerate coagulation by converting prothrombin to thrombin (25). Plasma contains a proteolytic enzyme precursor (plasminogen) which is readily converted by physical or chemical manipulation into the active enzyme (plasmin) $(26$, p. 28$)$. Conversion is also obtained by tissue extracts containing thromboplastic activity (27). Since it is difficult to exclude contamination of plasma or serum fractions by these substances, experiments were performed in which a mixture of thromboplastin, calcium and purified spca was incubated with gelatin. No proteolysis was demonstrable. 
Adsorption spectra of spca, Ac-globulin and prothrombin

Preparations of beef prothrombin, human prothrombin, Ac-globulin and partially purified spca (Run 3) showed essentially the same ultraviolet absorption spectra (Figure 5). However, the purest preparation of spca (Run 4), that described above, had an extinction coefficient markedly different in the range of $260-290 \mathrm{M} \mu$.

\section{Resume}

Purified spca can accelerate the coagulation of normal human blood, or blood in which coagulation is retarded by heparin, by exposure to siliconized surfaces, or by the clotting defect of hemophilia. In the latter two instances acceleration is associated with increased conversion of prothrombin to thrombin.

The serum Ac-globulin preparation similarly accelerated the clotting of normal human blood.

Spca is devoid of tryptic activity.

\section{DISCUSSION}

The serum prothrombin conversion accelerator (spca) which has been described in earlier reports has been separated from human serum and partially purified. This substance accelerates the conversion of prothrombin to thrombin in the

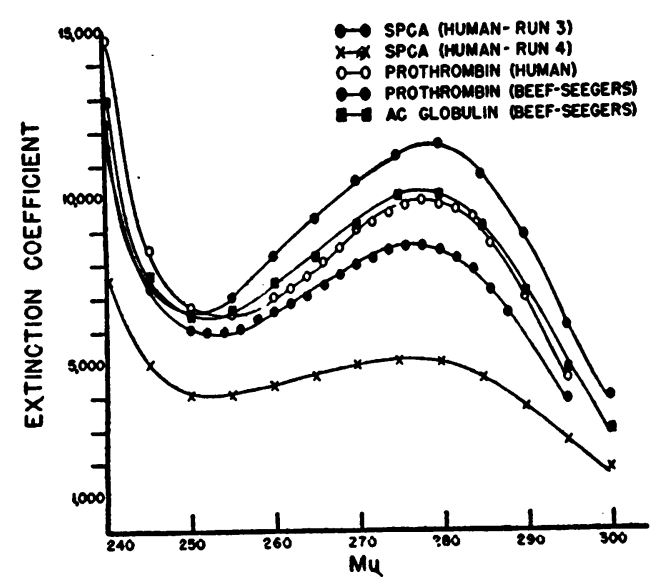

Fig. 5. Ultraviolet Absorption Spectrum (Beckman Spectrophotometer) of SPCA Serum Ac-Globulin aNd Prothrombin Preparations

Fractions were made up in concentration of 0.01 per cent. Run 4 represents purest spca fraction. Extinction coefficients on basis of gms. $\mathrm{N}$ per liter and $1.0 \mathrm{~cm}$. light path.

\section{TABLE VI}

Some comparative properties of spca and serum Ac-globulin

\begin{tabular}{|c|c|}
\hline Spca & Serum Ac-globulin \\
\hline $\begin{array}{l}\text { 1. Concentration higher in human } \\
\text { than bovine serum. } \\
\text { Higher in dog serum than hu- } \\
\text { man. }\end{array}$ & $\begin{array}{l}\text { High in bovine serum. } \\
\text { Very low in human and dog } \\
\text { serum.* }\end{array}$ \\
\hline $\begin{array}{l}\text { 2. Inert in two-stage system. } \\
\text { Active in one-stage on both } \\
\text { human and bovine prothrom- } \\
\text { bin. }\end{array}$ & $\begin{array}{l}\text { Active in one-stage system. } \\
\text { Active in two-stage system only } \\
\text { on purified prothrombin, not on } \\
\text { whole plasma. }\end{array}$ \\
\hline 3. Stable in human serum. & Very unstable in human serum. \\
\hline $\begin{array}{l}\text { 4. Purified material stable at } 37^{\circ} \mathrm{C} \\
\text { for at least five hours. } \\
\text { At } 4-5^{\circ} \mathrm{C} \text { for at least six weeks }\end{array}$ & $\begin{array}{l}\text { Two-stage activity unstable. } \\
\text { One-stage activity stable. }\end{array}$ \\
\hline $\begin{array}{l}\text { 5. Inert on prothrombin conver- } \\
\text { sion in aged human plasma }\end{array}$ & $\begin{array}{l}\text { Very active, but activity on aged } \\
\text { plasma is unstable. }\end{array}$ \\
\hline $\begin{array}{l}\text { 6. Removed completely by } \mathrm{BaSO}_{4} \\
\text { and } \mathrm{BaCO} \text { from human and } \\
\text { bovine serum. } \\
\text { Elutable by citrate solutions. }\end{array}$ & $\begin{array}{l}\text { Removed substantially. } \\
\text { Elutable by citrate. }\end{array}$ \\
\hline Different extinction & ents in ultraviolet range. \\
\hline
\end{tabular}

* According to Murphy and Seegers (17), dog serum exhibits little if any Ac-globulin activity on purified bovine prothrombin. Similarly, we have found dog serum devoid of Ac-globulin activity on purified human prothrombin.

presence of a plasma component which is labile. Because spca is evolved during the coagulation process, it is proposed that its elaboration underlies the "autocatalytic" mechanism of prothrombin conversion.

The question immediately arises as to the relationship between spca and serum Ac-globulin of Ware and his colleagues $(1-4)$ which has similar physiologic properties. These authors claim that plasma Ac-globulin, relatively inert, is converted to the active serum Ac-globulin during clotting. The process is referred to as "co-autocatalysis" since transformation is said to be induced by one of the products of coagulation, namely, thrombin. This theory is based upon observations that bovine serum fractions exhibit greater activity in promoting thrombin evolution from purified prothrombin than fractions similarly prepared from bovine plasma, and that the activity of plasma fractions can be enhanced by small amounts of thrombin.

Glaring differences appear to exist between spca and serum Ac-globulin (Table VI). These can be explained by the following hypothesis: "Serum Ac-globulin" comprises a mixture, or perhaps a chemical combination, of at least two important clotting components, plasma Ac-globulin and spca. These are distinctly different entities. The relatively greater activity of preparations derived from bovine serum is referable to spca which 
is elaborated during the transition from plasma to serum and which in the presence of plasma Acglobulin has a more profound effect on prothrombin conversion than plasma Ac-globulin alone.

Before the differences between spca and "serum Ac-globulin" are scrutinized, certain considerations regarding plasma Ac-globulin warrant clarification. That the rapid evolution of thrombin requires a non-prothrombin plasma constituent, can no longer be questioned. Such an entity has been described by several workers, and has been referred to as plasma Ac-globulin (1-4), Factor V $(5,28)$, and Labile Factor of Quick (18). Although further investigation is necessary to establish the identity or non-identity of these various factors, there is strong evidence to indicate that plasma Ac-globulin is identical with Labile Factor. The entities are labile, they deteriorate in parallel in stored human plasma $(18-20)$, and citrate retards the destructive process. They are partly adsorbed by $\mathrm{Mg}(\mathrm{OH})_{2}$, much less by $\mathrm{BaSO}_{4}(29,30)$. Furthermore, bovine plasma contains much more plasma Ac-globulin and Labile Factor than human plasma $(17,15)$, and the activity of both is negligible in human and canine serum $(17,15,31)$, in contrast to the high activity in bovine serum. Moreover, plasma Ac-globulin is demonstrable in human serum only under special conditions, i.e., when the blood is handled in siliconized apparatus and when determinations are made promptly after coagulation. Under such circumstances Labile Factor activity is also high (31). Accordingly, it is concluded, in agreement with Owren (28), that plasma Ac-globulin is identical with the Labile Factor of Quick.

Spca accelerates prothrombin conversion only in the presence of plasma Ac-globulin. Thus, spca is relatively inert on purified prothrombin but is markedly active when plasma Ac-globulin is provided, as it is in the modified one-stage procedure. This also explains why spca is inert on aged plasma in which plasma Ac-globulin has largely deteriorated. Similarly, human and dog serum, which are practically devoid of plasma Ac-globulin, are inactive on purified prothrombin even though they contain spca. On the other hand, the presence of plasma Ac-globulin in bovine serum, or in certain fractions thereof, accounts for their effects on both purified prothrombin and aged plasma.
The apparent lability of "serum Ac-globulin" as contrasted with the relative stability of spca is also explicable on the basis of the hypothesis that an important constituent of "serum Ac-globulin" is plasma Ac-globulin which is labile. Furthermore, since adsorption with $\mathrm{Mg}(\mathrm{OH})_{2}$ removes only part of the plasma Ac-globulin (the procedure used for preparing Ac-globulin from bovine plasma or serum $[1,4])$, it is not surprising that purified fractions appear more labile than the parent material $(3,4)$.

There can be no question that the "serum Acglobulin" preparation used in the present study contained a labile constituent lacking in aged plasma and essential for the rapid evolution of thrombin from purified prothrombin in an isolated system. However, it is apparent that the preparation also contained an additional clotting agent which was much more stable and which exhibited full prothrombin-conversion accelerating properties in a fresh plasma medium. In these respects the Ac-globulin preparation which was allowed to "deteriorate" was indistinguishable from spca. It is accordingly concluded that the material contained both plasma Ac-globulin and spca. The observation of Ware and Seegers (4) that their purest "serum Ac-globulin" showed two distinct components electrophoretically may be significant in this regard.

This concept is further substantiated by observations which validate certain theoretical expectations. Since spca is completely adsorbable by $\mathrm{BaSO}_{4}$ or $\mathrm{BaCO}_{3}$ whereas only small amounts of plasma Ac-globulin are thus removed, bovine serum treated with these agents should exhibit little spca activity but high plasma Ac-globulin activity. As expected, the adsorbed serum exhibited considerable "Ac-globulin activity" on purified prothrombin. Although the $\mathrm{BaSO}_{4}$ bovine serum could still accelerate one-stage prothrombin conversion (showed "spca activity") on human prothrombin diluted with human prothrombin-free plasma it was inert in a diluent of bovine source. This paradox can be readily explained. Its activity in the human-diluted system was probably due to the accelerating effect of the plasma Acglobulin left behind in the adsorbed serum and added to a system critically low in this clotting agent. It should be noted in this connection that under the same conditions bovine $\mathrm{BaSO}_{4}$ serum 
seemed to have even less effect than bovine $\mathrm{BaSO}_{4}$ plasma (Table IV). In the bovine-diluted system, on the other hand, plasma Ac-globulin is already present in optimal amounts. Under these conditions, therefore, addition of bovine serum rendered free of its spca by adsorption with $\mathrm{BaSO}_{4}$ should have no effect. This was confirmed by the observations.

We have seen that $\mathrm{BaSO}_{4}$ removes spca from bovine serum as it does from human serum. A fraction which exhibits spca activity in a bovineas well as in a human-diluted system can be recovered by elution with citrate. In contrast to eluates similarly prepared from human serum, the eluate obtained from bovine serum also shows "Ac-globulin activity" on purified prothrombin. This is believed due to small amounts of plasma Ac-globulin simultaneously adsorbed by the $\mathrm{BaSO}_{4}$ from the Ac-globulin-rich bovine serum. That extremely minute amounts of plasma Acglobulin will accelerate the evolution of thrombin from purified prothrombin has been emphasized by Seegers $(26$, p. 71$)$. The remarkable lability of the "Ac-globulin activity" of this bovine eluate containing only small amounts of plasma Acglobulin supports this interpretation.

Basic to the "autocatalytic" mechanism of thrombin evolution is the greater clot-promoting effect of serum or serum fractions compared with plasma. The theory of Ware and his co-workers (1-4) that the difference in activity is referable to conversion by thrombin of one substance, plasma Acglobulin, into "serum Ac-globulin," a much more active form of prothrombin activator, appears no longer tenable as an explanation of the "autocatalytic" process. In this connection it should be pointed out that conversion by thrombin of plasma, or plasma fractions containing plasma Ac-globulin, into a product which exhibits more activity does not necessarily indicate that it is the Ac-globulin which is being affected. An equally plausible interpretation might be that the thrombin converts spca precursor, a different plasma constituent, into spca. The evidence indicates that "serum Acglobulin" contains at least two important clotting components: spca and plasma Ac-globulin. The latter is a plasma component, is labile and is not readily adsorbed by $\mathrm{BaSO}_{4}$ or $\mathrm{BaCO}_{3}$ whereas spca is a serum factor which is relatively stable and which is adsorbed by these substances. It arises from an inert and as yet unidentified plasma precursor which, together with prothrombin, is also adsorbable by $\mathrm{BaSO}_{4}$ and elutable by citrate (32). Both plasma Ac-globulin and spca, and perhaps the precursor of spca, are adsorbed by $\mathrm{Mg}(\mathrm{OH})_{2}$, appearing in fractions separated by this adsorbing agent. Plasma Ac-globulin is essential for rapid prothrombin conversion. The reaction is further accelerated as spca is evolved during coagulation. Thus it appears that spca is the true "autocatalytic accelerator" of prothrombin conversion.

That spca requires plasma Ac-globulin for its activity raises provocative questions regarding their interaction and function in the process of prothrombin conversion. Plasma Ac-globulin is consumed during coagulation while spca is being elaborated (31). Yet all available evidence indicates that Ac-globulin is not its progenitor.

The difference in the ultraviolet absorption spectra of spca and Ac-globulin can be attributed to impurity of the Ac-globulin preparation, which is admitted to be no more than $50 \%$ pure $(4,26$, p. 75$)$. Crude spca preparations showed the same spectrum as the Ac-globulin and prothrombin fractions. With further purification the spca curve became different.

Of interest is the clot-promoting effect of spca on blood where coagulation is normal or retarded. It is generally agreed that inadequate release of thromboplastin underlies the defect in the clotting of hemophilic blood and blood exposed to siliconized surfaces. Heparin acts similarly by being an anti-thromboplastin. Presumably spca accelerates coagulation by potentiating the prothrombinconverting property of whatever thromboplastin is available, thereby increasing thrombin evolution. In harmony with this interpretation is the effect of spca on blood from a hemophiliac who had become resistant to the clot-promoting effects of normal plasma. The possible use of spca as a therapeutic agent in the treatment of various hemorrhagic disorders is being explored.

Although the method of separation and purification of spca delineated above is not proposed as the most efficient one, it has yielded a product which has given valuable information. A property most helpful in separation of the active substance is its adsorbability by $\mathrm{BaSO}_{4}$ and its elutability by solutions of citrate. Its similarity to pro- 
thrombin in these respects as well as others brings to mind the comments of Ware and associates (3, 4) regarding similarities between Ac-globulin and prothrombin.

While it is premature to estimate the degree of purity of the spca product obtained, it is evident that human serum contains less than $3 \mathrm{mgm}$. of spca per $100 \mathrm{ml}$. (calculated on the basis of normal serum having as many as 2500 units per 100 ml.).

Little can be said regarding the relationship of spca to other serum factors important in prothrombin conversion which have been described by other investigators : Factor VI of Owren (5), thrombokinase of Milstone (10) and the "prothrombinconverting factor" of Jacox (11). Owren's concept of (serum) Factor VI arising during clotting from (plasma) Factor $\mathrm{V}$ is strikingly similar to that of Ware and his co-workers regarding the transformation of plasma Ac-globulin into the more active "serum type." Owren has recently concluded that Factor V, plasma Ac-globulin and Labile Factor are identical (28). Few properties of Factor VI have been reported. However, it appears that this entity, too, is unstable in human serum, resembling "serum Ac-globulin." This difference from spca may similarly be due to the low concentration and instability of plasma Acglobulin in human serum. Spca may also be identical with thrombokinase. The latter arises in the presence of ionized calcium from a relatively inert precursor, prothrombokinase, which is unstable (10). The active enzyme is fairly stable, is adsorbable by $\mathrm{BaSO}_{4}$ and accelerates prothrombin conversion.

\section{CONCLUSIONS}

1. The prothrombin conversion accelerator of human serum has been separated and partially purified.

2. A property valuable in its isolation is its adsorbability by $\mathrm{BaSO}_{4}$ from which it can be eluted by citrate.

3. Human prothrombin can similarly be prepared from oxalated plasma by adsorption with $\mathrm{BaSO}_{4}$ and elution with citrate.

4. Purified spca shows the same properties previously recorded for the substance in serum. Additional properties are given.
5. Striking differences and some similarities between purified preparations of spca and serum Ac-globulin are delineated.

6. Most of the differences can be resolved on the theory that "serum Ac-globulin" comprises spca, together with a labile constituent of plasma which is essential for rapid prothrombin conversion in both the one- and two-stage systems. This agent is plasma Ac-globulin, which is identical with the Labile Factor of Quick. Considerable evidence is presented to support this concept.

7. Purified spca accelerated the coagulation of hemophilic blood, heparinized blood and silicone blood. The clot-promoting effects in hemophilic and silicone blood were associated with increased prothrombin consumption. This suggests the use of spca as a therapeutic agent in certain hemorrhagic disorders.

8. The relation of spca to prothrombin conversion factors described by others is briefly discussed.

\section{BIBLIOGRAPHY}

1. Ware, A. G., Guest, M. M., and Seegers, W. H., A factor in plasma which accelerates the activation of prothrombin. J. Biol. Chem., 1947, 169, 231.

2. Ware, A. G., Murphy, R. C., and Seegers, W. H., The function of Ac-globulin in blood clotting. Science, 1947, 106, 618.

3. Ware, A. G., and Seegers, W. H., Serum accelerator globulin: quantitative determination, purification and properties. Federation Proc., 1948, 7, 131.

4. Ware, A. G., and Seegers, W. H., Plasma accelerator globulin: partial purification, quantitative determination and properties. J. Biol. Chem., 1948, 172, 699.

5. Owren, P. A., The coagulation of blood; investigations on a new clotting factor. Acta med. Scandinav., 1947, Supp. 194.

6. Alexander, B., deVries, A., Goldstein, R., and Landwehr, G., A prothrombin conversion accelerator in serum. Science, 1949, 109, 545.

7. deVries, A., Alexander, B., and Goldstein, R., A factor in serum which accelerates the conversion of prothrombin to thrombin. I. Its determination and some physiologic and biochemical properties. Blood, 1949, 4, 247.

8. Alexander, B., deVries, A., and Goldstein, R., A factor in serum which accelerates the conversion of prothrombin to thrombin. II. Its evolution with special reference to the influence of conditions which affect blood coagulation. Blood, 1949, 4, 739.

9. Alexander, B., and deVries, A., A factor in serum which accelerates the conversion of prothrombin to thrombin. III. Its relationship to the coagula- 
tion defect of thrombocytopenic blood. Blood, 1949, 4, 747.

10. Milstone, J. H., Three-stage analysis of blood coagulation. J. Gen Physiol., 1948, 31, 301.

11. Jacox, R. F., Studies on the activation of a serum "prothrombin-converting factor." J. Clin. Invest., 1949, 28, 492.

12. Warner, E. D., Brinkhous, K. M., and Smith, H. P., Quantitative study on blood clotting: prothrombin fluctuations under experimental conditions. Am. J. Physiol., 1936, 114, 667.

13. Ware, A. G., and Seegers, W. H., Two-stage procedure for the quantitative determination of prothrombin concentration. Am. J. Clin. Path., 1949, 19, 471.

14. Alexander, B., and Landwehr, G., Prothrombin consumption, serum prothrombic activity and prothrombin conversion accelerator in hemophilia and thrombocytopenia. J. Clin. Invest., 1949, 28, 1511.

15. Unpublished observations.

16. Alexander, B., deVries, A., and Goldstein, R., A critique of prothrombin determination and its clinical significance. New England J. Med., 1949, 240, 403.

17. Murphy, R. C., and Seegers, W. H., Concentration of prothrombin and Ac-globulin in various species. Am. J. Physiol., 1948, 154, 134.

18. Quick, A. J., and Stefanini, M., The chemical state of the calcium reacting in the coagulation of blood. J. Gen. Physiol., 1948, 32, 191.

19. Alexander, B., and deVries, A., Human prothrombin: quantitative studies on the plasma labile factor and the restorative effects of normal, hypofibrinogenemic, and hemophilic plasma on the prothrombin of stored plasma. J. Clin. Invest., 1949, 28, 24.

20. Fahey, J. L., Ware, A. G., and Seegers, W. H., Stability of prothrombin and Ac-globulin in stored human plasma as influenced by conditions of storage. Am. J. Physiol., 1948, 154, 122.

21. Alexander, B., and deVries, A., Studies on hemophilia. V. The coagulation defect in hemophilia with particular reference to the conversion of prothrombin to thrombin and the evolution of the prothrombin conversion accelerator. Blood, 1949, 4, 752.

22. Pohle, F. J., and Taylor, F. H. L., The coagulation defect in hemophilia. The effect in hemophilia of intramuscular administration of a globulin substance derived from normal human plasma. J. Clin. Invest., 1937, 16, 741.

23. Jaques, L. B., Fidlar, E., Feldsted, E. T., and MacDonald, A. G., Silicones and blood coagulation. Canad. M. A. J., 1946, 55, 26.

24. Ferguson, J. H., and Lewis, J. H., "Accelerator globulin" and "antihemophilic globulin" in thrombin formation from aged prothrombin and in hemophilic blood. Proc. Soc. Exper. Biol. \& Med., 1948, 67, 228.

25. Eagle, H., and Harris, T. N., Studies in blood coagulation; the coagulation of blood by proteolytic enzymes. J. Gen. Physiol., 1937, 20, 543.

26. Tr. First Conf. Blood Clotting and Allied Problems. Josiah Macy, Jr. Foundation, 1948.

27. Astrup, T., and Permin, P. M., Fibrinolysis in animal organism. Nature, 1947, 159, 681.

28. Owren, P. A., The fifth coagulation factor (Factor V). Preparation and properties. Biochem. J., 1948, 43, 136.

29. Stefanini, M., and Quick, A. J., The effect of various adsorbants on the components of the prothrombin complex. Federation Proc., 1949, 8, 255.

30. Quick, A. J., and Stefanini, M., The concentration of the labile factor of the prothrombin complex in human, dog and rabbit blood: its significance in the determination of prothrombin activity. J. Lab. \& Clin. Med., 1948, 33, 819.

31. Alexander, B., Landwehr, G., and Goldstein, R., The labile factor of prothrombin conversion: its consumption in normal and abnormal blood coagulation. Federation Proc., 1950, 9, 4.

32. Alexander, B., and Landwehr, G., Evolution of a prothrombin conversion accelerator in stored human plasma and plasma fractions. Am. J. Physiol., 1949, 159, 322. 